\title{
Simulating the spatio-temporal dynamics of soil erosion, deposition, and yield using a coupled sediment dynamics and 3-D distributed hydrologic model
}

Tan $\mathrm{Zi}^{1}$, Mukesh Kumar ${ }^{1,2}$, Gerard Kiely ${ }^{3}$, Ciaran Lewis ${ }^{3}$, John Albertson ${ }^{1,4}$

1. Department of Civil and Environmental Engineering, Duke University, NC, USA

2. Nicholas School of the Environment, Duke University, NC, USA

3. Centre for Hydrology, Micrometeorology and Climate Change, Dept. of Civil and Environmental Engineering, University College Cork, Cork, Republic of Ireland

4. School of Civil and Environmental Engineering, Cornell University, NY, USA

Keywords: Distributed hydrologic model, soil erosion, sediment spatio-temporal dynamics, coupled modeling, sediment transport model, GEOtop model 


\section{Abstract}

Since soil erosion is driven by overland flow, it is fair to expect heterogeneity in erosion and deposition in both space and time. In this study, we develop and evaluate an open-source, spatially-explicit, sediment erosion, deposition and transport module for the distributed hydrological model, GEOtop, and use it to simulate the variations in sediment erosion and deposition. The integrated model was applied in Dripsey catchment in Ireland. The model reasonably captured the total discharge volume and suspended sediment yield (SSY) from the catchment, while also producing a physically plausible spatial pattern of soil erosion and deposition within the catchment. Further analyses showed that erosion and deposition areas in the watershed were dynamic and changed markedly between events. Also temporal variations in $S S Y$ were influenced by spatial patterns of surface soil saturation. The results highlight the need for physics-based modeling of coupled hydrologic processes to capture fine resolution sediment dynamics. 
Software Name: GEOtopSed

Developers: Tan Zi

Contact Address: Department of Civil and Environmental Engineering, Duke University, Durham, North Carolina, 27708, US

Email: tan.zi@duke.edu

Year First Available: 2015

Hardware Required: Desktop / Laptop with 2GHz CPU, 2GB RAM or more

Operating System Required: Macintosh OSX 10.4 or newer; Windows XP or newer; Linux Libraries Required: ASCII, FLUIDTURTLES, GEOMORPHOLOGYLIB, KeyPalette, MATH Cost: Free

Source Code: https://sourceforge.net/projects/geotopero/

Program Language: C 


\section{Introduction}

Soil erosion by rainfall and overland flow is a widespread threat to soil fertility and water quality. Accurate estimation of soil loss and its spatial distribution is often needed for pollutant risk analyses, reservoir management, agriculture productivity forecasts, and soil and water conservation. Furthermore, knowledge of areas at greatest risk provide for better targeted watershed management of important headwaters. In this regard, several distributed event-based models have been developed to obtain erosion estimates (DeRoo et al., 1996; Wicks and Bathurst, 1996; Morgan et al., 1998; Hessell, 2005; Jain et al., 2005; de Vente et al., 2008). These models generally account for the role of heterogeneity in land surface properties such as topography, soil and land cover, and meteorological forcing on soil erosion. Given that the detachment, transport, and deposition of soil are dominantly influenced by the velocity and volume of overland flow (Julien and Simons, 1985), which in turn may be influenced by antecedent soil moisture conditions (Legates et al., 2011; Penna et al., 2011; Jost et al., 2012; Chen et al., 2014; Hueso-González et al., 2015), subsurface heterogeneity (Lewis et al., 2012; Ghimire et al., 2013; Orchard et al., 2013; Zimmermann et al., 2013; Niu et al., 2014; Tao and Barros, 2014), and groundwater distribution (Kumar et al., 2009; Miguez-Macho and Fan, 2012; Rosenberg et al., 2013; Safeeq et al., 2014; von Freyberg et al., 2015), it is important to consider the coupled impacts of antecedent hydrologic states (soil moisture and groundwater distribution) and subsurface hydrogeologic properties on sediment generation and yield. In this regard, a number of physically based distributed erosion-deposition models have been developed (Knisel, 1980; Laflen et al., 1991; Smith et al., 1995; DeRoo et al., 1996; Wicks and Bathurst, 1996; Morgan et al., 1998; Johnson et al., 2000), but a majority of them only consider simplistic representations of vertical and lateral subsurface water flow. For example, most of the aforementioned models do not account for the lateral subsurface water movement, or the coupled dynamic interactions between vadose zone and the groundwater table, or the evolution of soil moisture and groundwater with evapotranspiration. This may limit the applicability of these models to a few events (Hessel et al., 2006; Mati et al., 2006; Ramsankaran et al., 2013) or to regimes where the dynamic role of antecedent conditions and subsurface heterogeneity on erosion are not large enough. Heppner et al. (2006) made significant headway in this direction by coupling sediment processes within an integrated hydrologic model, InHM (VanderKwaak and 
Loague, 2001). The study specifically evaluated the rainfall splash erosion component of the model on a 6 m by $2.4 \mathrm{~m}$ plot. Heppner et al. (2007) used the same model to perform sedimenttransport simulations for six events in a $0.1 \mathrm{~km}^{2}$ rangeland catchment. It is to be noted that InHM solves subsurface flow using the variably saturated 3D-Richards equation, while surface flow is simulated using diffusion wave approximation of St. Venant equation. Another notable effort in this direction was by Kim et al., (2013), who coupled sediment processes within a hydrologic and hydrodynamic model tRIBS-OFM and validated their model against analytical solutions. The study evaluated sediment yield simulations for 10 events in the $0.036 \mathrm{~km}^{2}$ Lucky Hills watershed located in southeastern Arizona, USA. Notably, tRIBS-OFM used a gravitydominated formulation (Cabral et al., 1992) to simulate vadose zone flow and a quasi-3D Boussinesq's equation under the Dupuit-Forchheimer assumptions to simulate groundwater flow (Ivanov et al., 2004). Development of these physically-based integrated models of hydrology and sediment dynamics has opened new opportunities, especially in regards to understanding the impact of the hydrologic state on spatio-temporal distribution of erosion, deposition and yield.

Here, we develop an open-source, spatially-explicit, sediment erosion/deposition module for a 3D surface-subsurface hydrologic model, GEOtop (Rigon et al., 2006), and evaluate its applicability in explaining the sediment yield dynamics in a $15 \mathrm{~km}^{2}$ area grassland watershed. The sediment dynamics model developed here takes advantage of the GEOtop simulated distributed hydrological states such as moisture content, surface flow depth, and flow velocity. The model accounts for the influence of spatial heterogeneities in land surface characteristics, subsurface hydrogeology, and antecedent conditions in the generation of overland flow, and hence on the erosion and deposition of sediment in the watershed. The coupled model is then used to answer four pointed questions: a) Does the daily suspended sediment yield from the watershed varies monotonically with precipitation amount/intensity? b) Does the source/sink area of sediments vary spatially from one event to other? c) Is the variation in erosion and deposition in both space and time driven by hydrologic state, specifically the surface soil saturation state? and d) To what extent does the linear relation between erosion and the slopelength factor (product of specific catchment area and slope) hold? 


\section{Process Formulation, Site Descriptions and Model Implementation}

\subsection{The GEOtop model: A short review}

The open-source GEOtop model (Rigon et al., 2006) is process based and simulates core hydrological processes such as unsaturated flow, saturated flow, overland flow, stream flow generation/routing, and surface energy balances. Overland flow modeling is performed using the kinematic wave approximation of St. Venant equation while subsurface flow and soil moisture simulations are performed by solving a variably-saturated representation of 3-D Richards equation. The model has been extensively tested and validated in Bertoldi (2004). The water and energy balance calculations in GEOtop were recently refined to account for soil freezing and thawing effects (Endrizzi et al., 2014). With detailed water and energy balance modules, GEOtop provides satisfactory simulations of evapotranspiration and soil moisture dynamics (Bertoldi et al., 2014; Della Chiesa et al., 2014), which are important for erosion estimation at multiple scales. As open source software (http://www.geotop.org/wordpress/), the GEOtop model provides a complete hydrological model framework with ease for extensions. One such example is the incorporation of landslide occurrence prediction within the GEOtop framework by Simoni et al. (2008).

\subsection{Process formulation of the sediment dynamics model}

The sediment dynamics model developed here takes advantage of the GEOtop simulated distributed hydrological states such as moisture content, surface flow depth, and flow velocity. Here we only highlight the aspects of the model that are most relevant to the sediment erosion, deposition and transport modeling.

After updating the soil moisture in each soil layer by solving the 3D Richards equation, the surface overland flow in GEOtop is routed using the kinematic wave approximation of the Saint-Venant equation in each grid cell:

$$
\frac{\partial h}{\partial t}+\frac{\partial q}{\partial x}=q_{L}
$$

where $h$ is depth of overland flow [m], $x$ is a local coordinate system oriented along the flow

direction $[\mathrm{m}] ; q$ is flow rate per unit width $\left[\mathrm{m}^{2} \mathrm{~s}^{-1}\right]$, and $q_{L}$ is vertical inflow or outflow rate (to 
the surface water) per unit area $\left[\mathrm{m} \mathrm{s}^{-1}\right]$. The overland flow equation is coupled to the continuity equation of sediment transport at each time step using:

$$
\frac{\partial h C}{\partial t}+\frac{\partial q C}{\partial x}=E_{x}
$$

where $C$ is sediment concentration in the overland flow within each cell $\left[\mathrm{kg} \mathrm{m}^{-3}\right]$, and $E_{x}$ is the exchange rate of sediment per unit surface area $\left[\mathrm{kg} \mathrm{m}^{-2} \mathrm{~s}^{-1}\right]$ at the interface of soil and water. $E_{x}$ is composed of three major mechanisms: rainfall splash detachment $\left(D_{R}\right)$, flow detachment $\left(D_{F}\right)$ and deposition $\left(D_{P}\right)$, as:

$$
E_{x}=D_{R}+D_{F}-D_{P}
$$

$D_{R}\left[\mathrm{~kg} \mathrm{~m}^{-2} \mathrm{~s}^{-1}\right]$ is approximated by DeRoo et al. (1996):

$$
D_{R}=\left(0.1033 \frac{K e}{\zeta} e^{-1.48 \mathrm{~h}}+3.58\right) * I
$$

where $\zeta$ is soil cohesion $[\mathrm{kPa}], K e$ is rainfall kinetic energy $\left[\mathrm{J} \mathrm{m}^{-2} \mathrm{~mm}^{-1}\right]$, and $I$ is precipitation intensity $\left[\mathrm{mm} \mathrm{h}^{-1}\right] . D_{F}$ and $D_{P}\left[\mathrm{~kg} \mathrm{~m}^{-2} \mathrm{~s}^{-1}\right]$ are related to transport capacity $\left(T_{C}\right)$ based on the erosiondeposition theory proposed by Smith et al. (1995).

$$
\begin{aligned}
& D_{F}=\left(T_{C}-C\right) * y * v_{s} \\
& D_{P}=\left(T_{C}-C\right) * v_{s}
\end{aligned}
$$

where $y$ is an efficiency coefficient that is a function of soil cohesion (DeRoo et al., 1996), and $v_{s}$ is settling velocity of the particles $\left[\mathrm{m} \mathrm{s}^{-1}\right]$. The dependence of soil cohesion on soil moisture (Bullock et al., 1988) and root tensile strength (Wu et al., 1979) is captured using:

$$
\begin{aligned}
& \zeta_{s}=\left(\frac{\theta}{\theta_{s}}\right)^{2} \zeta_{s s} \\
& \zeta_{a d d}=1.2 * R_{S} \\
& \zeta=\zeta_{a d d}+\zeta_{s}
\end{aligned}
$$


where $\zeta_{s}, \zeta_{s s}, \zeta_{a d d}$ are bare soil cohesion, saturated bare soil cohesion and additional cohesion by roots respectively, and $R_{S}$ is the root total tensile strength $[\mathrm{kPa}]$. The transport capacity is based on the experiments conducted by Govers (1990):

$$
T_{C}=a\left(\omega-\omega_{c r}\right)^{b} * \rho
$$

where $\omega$ is the unit stream power $\left[\mathrm{m} \mathrm{s}^{-1}\right.$ ] (Yang, 1972), $\omega_{c r}$ is the critical power that initiates flow detachment of soil particles [ $\left.\mathrm{m} \mathrm{s}^{-1}\right], \rho$ is the density of soil particles $\left[\mathrm{kg} \mathrm{m}^{-3}\right]$, and $a$ and $b$ are empirical parameters related to soil particle size.

The sediment mass balance in each stream channel reach was calculated using:

$$
\frac{\partial h_{c} C_{c}}{\partial t}+\frac{\partial q_{c} C_{c}}{\partial x}=I_{n}
$$

where $q_{c}$ is the discharge per unit width in channel [ $\left.\mathrm{m} \mathrm{s}^{-1}\right], h_{c}$ is the water depth of channel [m], $C_{c}$ is sediment concentration in channel $\left[\mathrm{kg} \mathrm{m}^{-3}\right]$, and $I_{n}$ is the sediment exchange rate per unit area between adjacent land cells and the channel cell $\left[\mathrm{kg} \mathrm{m}^{-2} \mathrm{~s}^{-1}\right]$. The suspended sediment yield $(S S Y)[\mathrm{kg}]$ at the outlet of the catchment was the integration of suspended sediments over the period of interest:

$$
S S Y=\int Q_{o l} C_{o l} d t
$$

where $Q_{o l}$ is the discharge rate at outlet $\left[\mathrm{m}^{3} \mathrm{~s}^{-1}\right], C_{o l}$ is the sediment concentration at the outlet cell $\left[\mathrm{kg} \mathrm{m}^{-3}\right]$ and $d t$ is an hourly integration time step. The period of integration in the ensuing analyses varied from hourly to annual scale and has been appropriately identified at relevant locations.

\subsection{Site descriptions}

The coupled model was tested at a small experimental catchment, at Dripsey, Ireland (Figure 1). The Dripsey catchment is located approximately $25 \mathrm{~km}$ northeast of Cork, and has an area of 15 $\mathrm{km}^{2}$. The elevation of this catchment ranges from 60 to $210 \mathrm{~m}$. It is a beef and dairy producing agricultural catchment and is almost $100 \%$ covered by perennial ryegrass. The catchment slopes gently, with around $85 \%$ of the area having less than $3 \%$ grade. Gleys and podzols are the two major soil types. The experimental field site is managed by the Hydromet team of the University College Cork (UCC). There is a meteorological flux tower at the top of the catchment (elevation 
$192 \mathrm{~m}$ ) where radiation, wind speed, air temperature, surface temperature, relative humidity, and soil moisture (at five depths) have been measured since 1998 (Albertson and Kiely, 2001). All the meteorological data from the site are archived in the FLUXNET repository (http://fluxnet.ornl.gov). At the catchment outlet (elevation $60 \mathrm{~m}$ ), stream stage was continuously recorded by a water level recorder just upstream of a rectangular weir at the outlet of catchment. Sediment and nutrient export from the catchment were also measured from 2002 to 2003 (Lewis, 2003; Lewis, 2011).

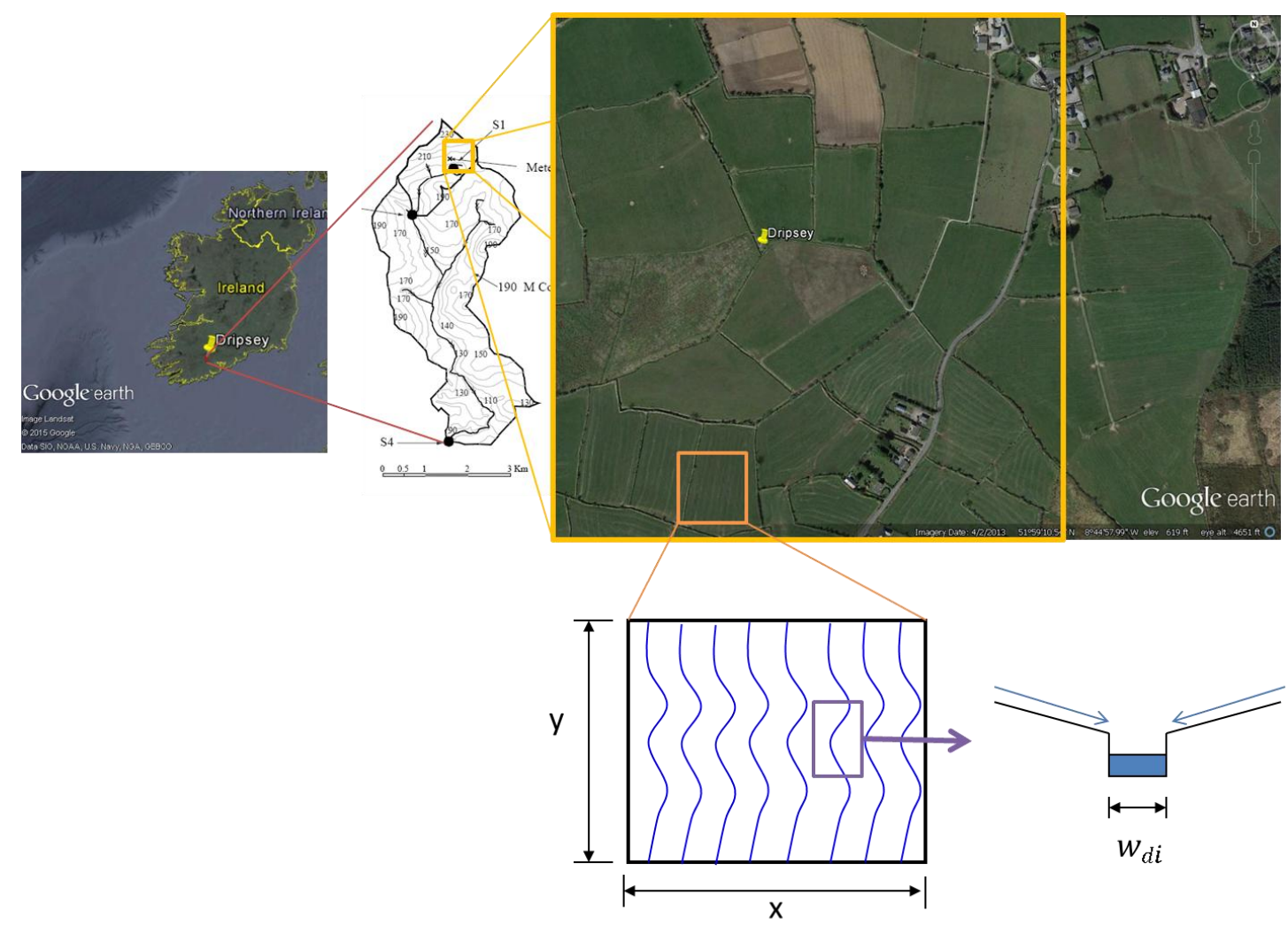

Figure 1 Location of Dripsey catchment in County Cork, Ireland. The location of the meteorological tower is where "Dripsey" is marked in yellow. The right top panel is the Google Earth image of Dripsey catchment. The lower panel shows the conceptualization of rills (discussed in section 2.5).

The climate in the study region is temperate maritime, and is characterized by high humidity and a lack of temperature extremes during the year. The mean annual precipitation locally is approximately $1400 \mathrm{~mm}$. The annual precipitation in the Dripsey catchment for year 2002 and 
2003 was $1823 \mathrm{~mm}$ and $1178 \mathrm{~mm}$, respectively. Winter and spring were the wetter seasons while summer was generally dry (Figure 2). Suspended sediment losses over the catchment were estimated from measured data of stream flow volume and suspended sediment concentration and recorded on a monthly basis.
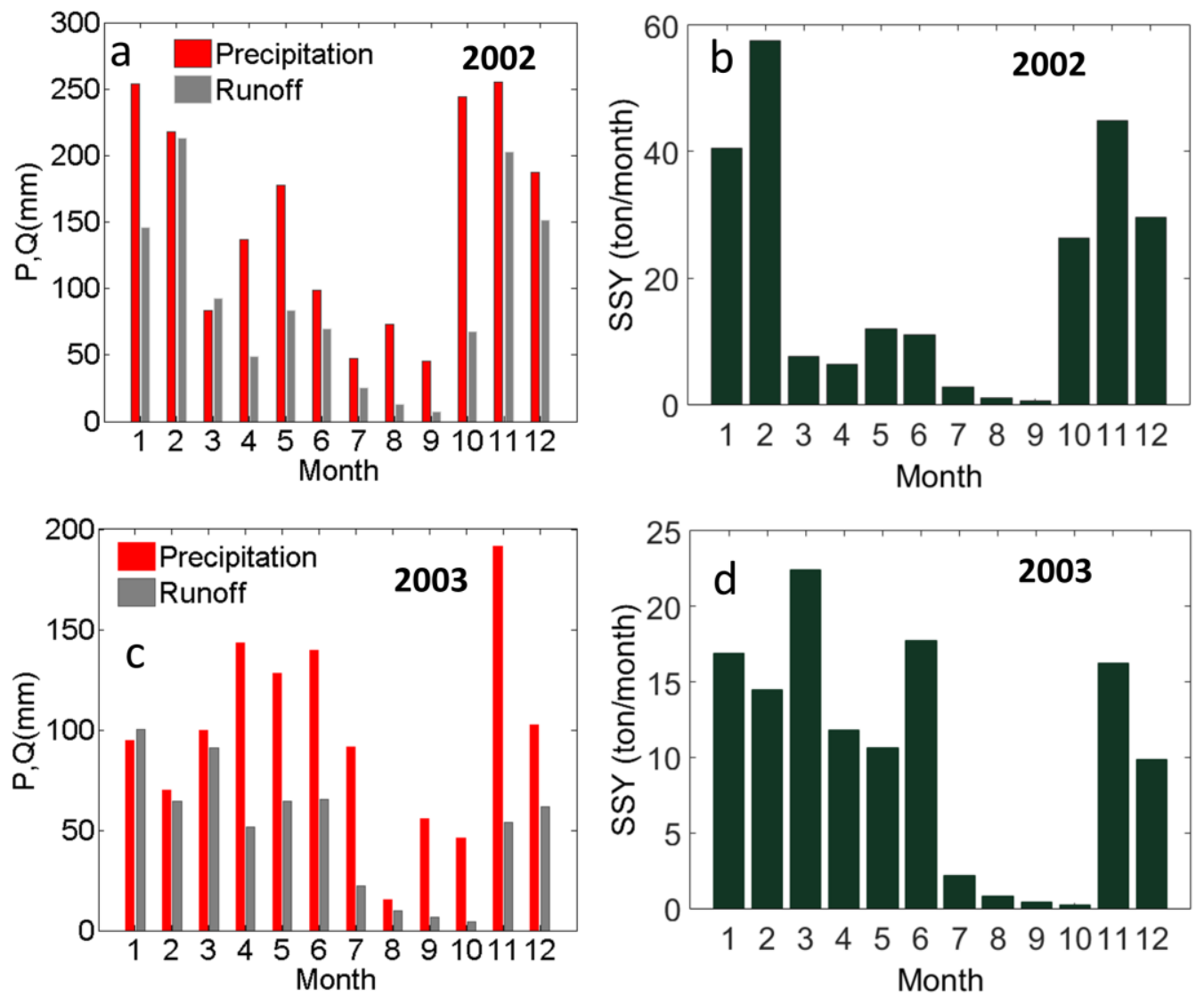

Figure 2 Observed monthly variations in precipitation (P), discharge volume (Q) and suspended sediment losses (SSY) in the Dripsey catchment

\subsection{Model input data}

GEOtop requires a digital elevation model (DEM), land use/land cover (LULC) map, and soil type map to simulate the hydrological processes for a catchment. The soil type map and soil parameters were obtained from Irish Forestry soils (IFS) database. The LULC map was from Corine land cover 2000 database. All digital maps were resampled to $50 \mathrm{~m} \times 50 \mathrm{~m}$ spatial resolution. Meteorological data such as precipitation, temperature, incoming shortwave radiation, air pressure, relative humidity, wind speed and direction in half-hourly time steps were collected 
at the HYDROMET flux tower at Dripsey. The stream flow and suspended sediment concentration data (collected by the water level recorder at the outlet of catchment) were used to both calibrate and validate the model.

\subsection{Model implementation in Dripsey catchment}

The integrated model simulations were performed at $50 \mathrm{~m} \times 50 \mathrm{~m}$ spatial resolution and an hourly temporal resolution. While overland flow (from either saturation excess or infiltration excess) is generated over the entire land surface cell in the original GEOtop model, a rill width ratio $\left(w_{d x}\right)$ parameter was introduced in the sediment dynamics model to account for the flow organization within each cell. The assumption here is that the generated overland flow is transferred into small rills (Figure 1) in which overland flow gets concentrated and the potential of rill erosion is high. The rill width ratio $\left(w_{d x}\right)$ was calculated using the following equation:

$$
w_{d x}=\frac{\sum_{i} w_{d i}}{x_{w}}
$$

where $i$ is the rill index within a cell, $w_{d i}$ is the width of $i^{t h}$ rill [m], and $x_{w}$ is the width of the cell [m]. In other words, $w_{d x}$ is the fraction of a grid cell covered by overland flow, when overland flow is active. The soil erosion calculations were accordingly modified to account for erosion under a redistributed overland flow regime. Rain splash detachment occurred in the entire cell while the flow detachment only occurred within the rills. While rill characteristics can be observed, the absence of relevant data for the site leads us to consider rill characteristics as a calibration parameter. This is an important area for future research attention.

The model accounts for erosion, deposition, and transport of suspended sediment on the hillslopes. However, considering that the bank and bed erosion and deposition in first order river channels are not significant (Golubev, 1982), these processes were not included in sediment dynamics calculations in the channel. All the sediment entering the channels was assumed to directly reach the outlet of the watershed. It is to be acknowledged that this assumption may cause bias in suspended sediment yield estimates, especially from large basins wherein river beds and banks can be a significant source and/or sink of sediment. 


\section{Parameter Sensitivity and Model Performance Evaluation}

\subsection{Sensitivity analysis}

A global multivariate sensitivity analyses was first conducted to evaluate the role of physicsbased parameters that may impact soil erosion and deposition. The methodology is based on a Monte Carlo framework, and can be used to analyze the influence of a parameter while also considering the influence of all other parameters at the same time (Franks et al., 1997). The parameters chosen for the sensitivity analysis included hydrologic properties that may influence runoff generation (Table 1) and land properties that may influence soil erodibility (Table 2). Each parameter was assigned a wide range spanning previously reported values in literature (Table 1, Table 2). Model simulations were conducted using a single rainfall event for 10,000 random sets of parameters, which were sampled from uniform distributions across the specified parameter ranges. Based on the rank of Nash-Sutcliffe (NS) coefficients for each parameter set, the 10,000 parameter sets were divided into ten performance classes, each with 1000 parameter sets. The classes were ranked by $N S$ coefficient from low to high, i.e. Class 1 consisted of parameter sets with lowest NS coefficient while Class 10 comprised of parameter sets with highest $N S$ coefficient. A numerical sensitivity index ( $N S I)$ was used to quantify the sensitivity (Montaldo et al., 2003):

$$
N S I=\frac{1}{n_{c} N x_{\text {range }}} \sum_{i=1}^{n_{c}} \sum_{j=1}^{N} x_{d}(i, j)
$$

where $x_{d}$ is the difference between the parameter values of two classes for the $j^{\text {th }}$ cumulative frequency and for $i^{\text {th }}$ pair of cumulative frequency curves, $n_{c}$ is the total number of pairs of cumulative frequency classes (with 10 classes, $n_{c}=45$ ), and $N$ is the number of cumulative frequency values in each performance class ( $N=1000$ in this case). $x_{\text {range }}$ is the range of parameter values. NSI is an indicator of the distance between each class. A larger value of NSI for a parameter indicates higher sensitivity to it.

Table 1 Ranges and numerical sensitivity index (NSI) of hydrologic parameters

\begin{tabular}{|l|l|l|l|}
\hline Variable Name & Description & Range & NSI \\
\hline$A$ & Leaf area index & $0.1-4$ & 0.073 \\
\hline
\end{tabular}




\begin{tabular}{|c|c|c|c|}
\hline$C_{F}$ & Canopy fraction & $0-1$ & 0.0009 \\
\hline$\overline{C_{m}}$ & Chezy's roughness coefficient & $0.01-5$ & 0.0325 \\
\hline$w_{d x}$ & Rill width ratio & $0.01-1$ & 0.073 \\
\hline$\overline{D_{l}[\mathrm{~mm}]}$ & Soil depth of first layer & $25-300$ & 0.0731 \\
\hline$K_{h_{-} L I}\left[\mathrm{~mm} \mathrm{~s}^{-1}\right]$ & Horizontal saturated conductivity $\left(1^{\text {st }}\right.$ layer $)$ & $0.00036-0.12$ & 0.0008 \\
\hline$K v_{-L I}\left[\mathrm{~mm} \mathrm{~s}^{-1}\right]$ & Vertical saturated conductivity $\left(1^{\text {st }}\right.$ layer $)$ & $0.00036-0.06$ & 0.0322 \\
\hline$\Theta_{r_{-} L l}$ & Residual water content ( $1^{\text {st }}$ layer $)$ & $0.03-0.06$ & 0.0033 \\
\hline$\Theta_{w_{-} L I}$ & Wilting point $\left(1^{\text {st }}\right.$ layer $)$ & $0.06-0.16$ & 0.0040 \\
\hline$\Theta_{f c \_l l}$ & Field capacity( $1^{\text {st }}$ layer $)$ & $0.3-0.5$ & 0.0050 \\
\hline$\theta_{S_{-} L 1}$ & Saturated water content $\left(1^{\text {st }}\right.$ layer $)$ & $0.3-0.6$ & 0.0045 \\
\hline$K_{h_{-} L 2}\left[\mathrm{~mm} \mathrm{~s}^{-1}\right]$ & Horizontal saturated conductivity ( $2^{\text {nd }}$ layer $)$ & $0.00036-0.12$ & 0.0012 \\
\hline$K v_{-L 2}\left[\mathrm{~mm} \mathrm{~s}^{-1}\right]$ & Vertical saturated conductivity ( $2^{\text {nd }}$ layer $)$ & $0.00036-0.06$ & 0.0001 \\
\hline$\Theta_{r_{-} L 2}$ & Residual water content ( $2^{\text {nd }}$ layer $)$ & $0.03-0.06$ & 0.0035 \\
\hline$\Theta_{w_{-} L 2}$ & Wilting point $\left(2^{\text {nd }}\right.$ layer $)$ & $0.06-0.16$ & 0.0006 \\
\hline$\Theta_{f c_{C} L 2}$ & Field capacity $\left(2^{\text {nd }}\right.$ layer $)$ & $0.3-0.5$ & 0.0013 \\
\hline$\theta_{S_{-} L 2}$ & Saturated water content( $2^{\text {nd }}$ layer $)$ & $0.3-0.6$ & 0.0062 \\
\hline$K_{h_{-} L 3}\left[\mathrm{~mm} \mathrm{~s}^{-1}\right]$ & Horizontal saturated conductivity $\left(3^{\text {rd }}\right.$ layer $)$ & $0.00036-0.12$ & 0.0076 \\
\hline$K v_{-L 3}\left[\mathrm{~mm} \mathrm{~s}^{-1}\right]$ & Vertical saturated conductivity ( $3^{\text {rd }}$ layer $)$ & $0.00036-0.06$ & 0.0119 \\
\hline$\Theta_{r_{-} L 3}$ & Residual water content ( $3^{\text {rd }}$ layer) & $0.03-0.06$ & 0.0026 \\
\hline$\Theta_{w_{L} L 3}$ & Wilting point $\left(3^{\text {rd }}\right.$ layer $)$ & $0.06-0.16$ & 0.0006 \\
\hline$\Theta_{f c_{C} L 3}$ & Field capacity $\left(3^{\text {rd }}\right.$ layer $)$ & $0.3-0.5$ & 0.0048 \\
\hline$\theta_{S_{-} L 3}$ & Saturated water content $\left(3^{\text {rd }}\right.$ layer $)$ & $0.3-0.6$ & 0.0005 \\
\hline
\end{tabular}


Table 2 Ranges and numerical sensitivity index (NSI) of erosion and sediment dynamics parameters

\begin{tabular}{|c|c|c|l|}
\hline Variable Name & Description & Range & NSI \\
\hline$C_{m}$ & Chezy's roughness coefficient & $0.01-5$ & 0.3569 \\
\hline$R_{s}[\mathrm{MPa}]$ & Root tensile strength & $0.001-0.1$ & 0.0236 \\
\hline$R_{a}$ & Root area ratio & $0.001-0.1$ & 0.0033 \\
\hline$w_{d x}$ & Rill width ratio & $0.01-1$ & 0.3569 \\
\hline$D_{50}[\mu \mathrm{m}]$ & Median particle size & $5-200$ & 0.3563 \\
\hline$\zeta[\mathrm{kPa}]$ & Soil cohesion & $0-30$ & 0.0237 \\
\hline
\end{tabular}

The sensitivity of hydrologic and land surface parameters are presented individually here. Among the 23 parameters selected for the hydrological sensitivity analysis, leaf area index $(\alpha)$, rill width ratio $\left(w_{d x}\right)$, depth of the first soil layer $\left(D_{1}\right)$, Chezy's roughness coefficient $\left(C_{m}\right)$, and vertical hydraulic conductivity of the first soil layer $\left(K_{v_{-} L 1}\right)$ were found to be among the five most sensitive parameters for runoff generation (Table 1). Similarly, $C_{m}, w_{d x}$ and $D_{50}$ were observed to be the three most sensitive parameters for sediment yield simulations (Table 2). Root tensile strength $\left(R_{s}\right)$ and soil cohesion $(\zeta)$ also were important players in sediment yield simulations, though to a lesser extent than the other three parameters identified above. Among the three most sensitive parameters for sediment yield, $D_{50}$ can be estimated from soil texture and $C_{m}$ can be related to land cover and land use. $w_{d x}$ can be highly varied between different watersheds or land parcels depending on micro-topographic heterogeneity arising from natural causes or implementation of agricultural practices (e.g. tillage farming). The other two sensitive parameters for sediment yield simulations: root tensile strength $\left(R_{S}\right)$ and soil cohesion $(\zeta)$, are correlated, as $R_{s}$ proportionally affects $\zeta$ (see equations 7, 8, and 9) and both the parameters have a tendency to reduce soil erosion. 

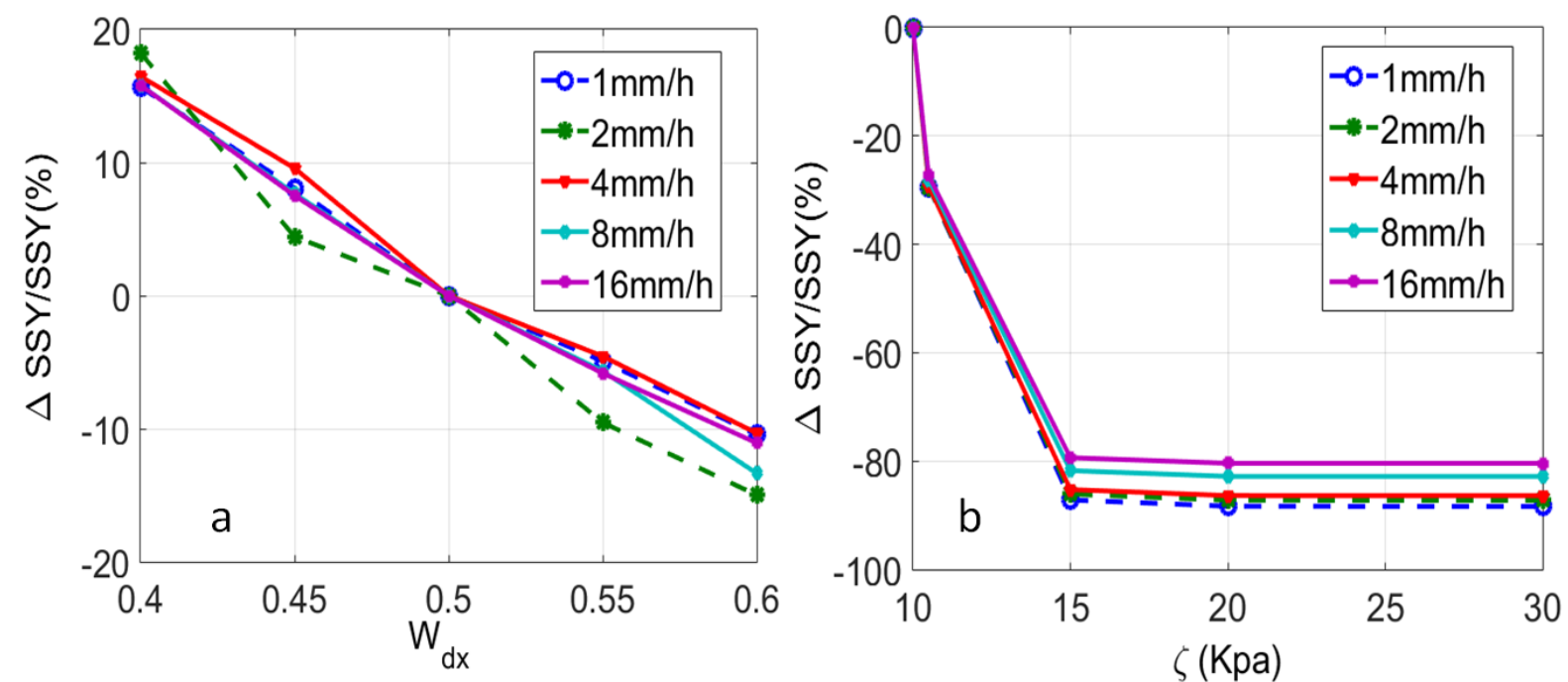

Figure 3 Sensitivity of rill width ratio, $w_{d x}(a)$ and soil cohesion, $\zeta(b)$ on suspended sediment yield (SSY) for a range of precipitation intensities.

Having identified the most sensitive parameters, next a univariate sensitivity experiment was performed to investigate the role of two sensitive but independent parameters $\left(w_{d x}\right.$ and $\left.\zeta\right)$ on erosion simulations. This involved forcing the model with a $32 \mathrm{~mm}$ precipitation event of 24 hours duration. As shown in Figure 3, increasing $w_{d x}$ caused a reduction in suspended sediment losses. This is because for a wider rill, overland flow depth and velocity is smaller resulting in a smaller shear stress between water and soil surface to detach the soil particles. It is to be noted that the relative changes in $w_{d x}$ (base value equals to 0.5 ) were larger than the relative changes in $S S Y$. For example, $20 \%$ decrease in $w_{d x}$ increased sediment yield by $15 \%$. This was due to the offset effect of reduction in flow detachment area when the rills are narrower.

Five additional sensitivity experiments with varying rainfall intensities, but with identical precipitation amount, were conducted to evaluate potential controls of event characteristics on the sensitivity of sediment yield to $w_{d x}$. Different rainfall intensities did not show significant impacts on sensitivity analysis, indicating that flow detachment rather than splash erosion, was the major driving force for water erosion in Dripsey catchment. This is possibly caused by the dense grassland vegetation cover within Dripsey catchment which protected the soil surface from detachment by raindrops. Similar sensitivity experiment for soil cohesion $(\zeta)$ showed that the sediment yield decreased with increase in $\zeta$. The influence of soil cohesion on erosion was the 
largest when cohesion value was between 10 to $20 \mathrm{kPa}$. Notably, as the precipitation intensity increased, the sensitivity to soil cohesion decreased.

It is to be noted that sediment yield simulations could be influenced both by parameters that control rainfall-runoff processes and parameters that define the land surface and soil characteristics. This makes calibration of a physically based integrated erosion-deposition models much more challenging than integrated hydrologic models.

\subsection{Model Performance During Calibration and Validation Periods}

\subsubsection{Calibration period}

The calibration was carried out using hourly flow data and suspended sediment concentration data from Jan $1^{\text {st }}, 2002$ to Mar $14^{\text {th }}, 2002$ (73 days, 10\% of the observed data). The GEOtop model spin-up was performed using the meteorological data of Dec, 2001. The calibration process mainly focused on the most sensitive parameters, as identified in the global sensitivity analyses. $C_{m}, D_{l}$, and $w_{d x}$ were the three major parameters calibrated for the flow simulation. $\zeta$ and $D_{50}$ were mainly calibrated for erosion simulation. The model calibration was based on both mass balance and goodness of fit of hydrograph and sedigraph. The goal was to at least limit the relative bias of total discharge volume and total $S S Y$ to less than $15 \%$ and to have $R^{2}$ of daily average flow rate and daily total $S S Y$ to be larger than 0.75 . 

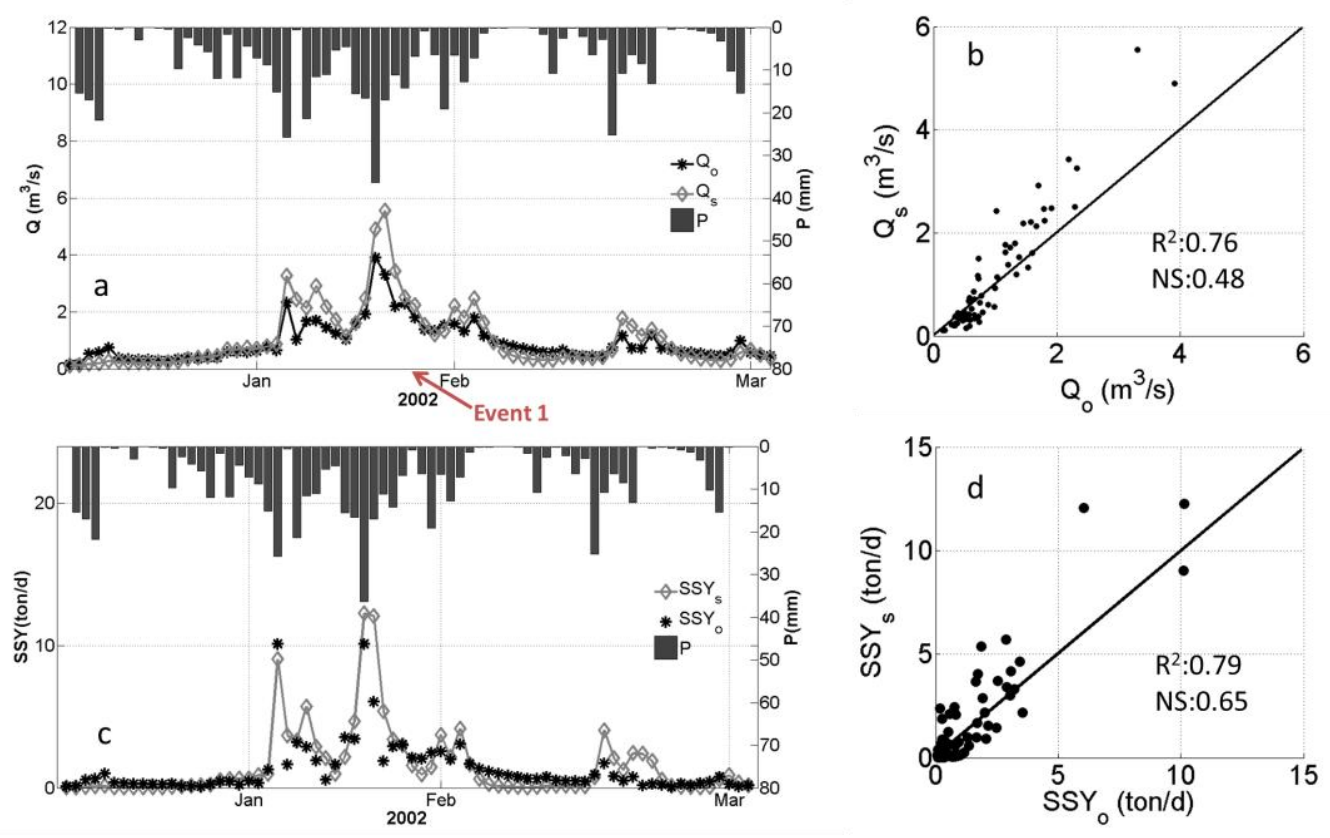

Figure 4 Model estimates of daily discharge and daily suspended sediment yield (SSY) during the calibration period. (a) plot of observed (with subscription ' $o$ ') and simulated (with subscription 's') daily average stream flow rate; (b) scatter plot of observed and simulated daily average stream flow rate; (c) plot of observed and simulated daily total SSY; (d) scatter plot of observed and simulated daily total SSY.

The observed and simulated stream flow series in calibration period are shown in Figure 4a and Figure 4b. Observed and simulated total discharge volumes per unit area over the calibration period were $411 \mathrm{~mm}$ and $472 \mathrm{~mm}$, respectively (relative bias $\sim 15 \%$ ). The $R^{2}$ and Nash-Sutcliff coefficient (NS) were 0.76 and 0.48 , respectively. The index of agreement (IOA) was 0.92 and the root mean square error (RMSE) was $3.03 \mathrm{~mm} / \mathrm{day}$. All the selected indices showed a satisfactory simulation of stream flow, indicating that the model was generally able to capture both the timing and magnitude of flow rate. It is to be noted, however, that the stream flow peaks were overestimated in the simulation results, as with the total flows.

In regards to the estimates of suspended sediment yield (SSY), the model also showed good agreement with the observations. The observed and modeled total suspended sediment losses were 72.76 and 79.94 tons, respectively, for the calibration period. The relative bias was 9.87\%. $R^{2}$ and $N S$ were 0.79 and 0.65 , respectively (Figure 4c, Figure 4d). The RMSE was 0.83 ton/day and $I O A$ was 0.93 . The peaks of erosion events were generally captured by the model, both in timing and magnitude. The $S S Y$ during the peak flow were overestimated, just like the overestimation of high flows by the hydrologic model. 


\subsubsection{Validation period}

The model was validated using data from Mar $15^{\text {th }}, 2002$ to the end of 2003. As shown in Figure 5, observed and simulated total discharge per unit area were $1303.8 \mathrm{~mm}$ and $1287.7 \mathrm{~mm}$, respectively. Figure $5 \mathrm{~b}$ shows that the time series of cumulative observed and simulated discharge volume matched each other for most of the period, and the relative bias was only $1.2 \%$. In general, the model reasonably simulated both the timing and magnitude of stream flow during the validation period (RMSE: $1.47 \mathrm{~mm} /$ day; $N S: 0.5$; and IOA: 0.9). However, the model simulation overestimated high flows and underestimated low flows, much like it performed during the calibration period.
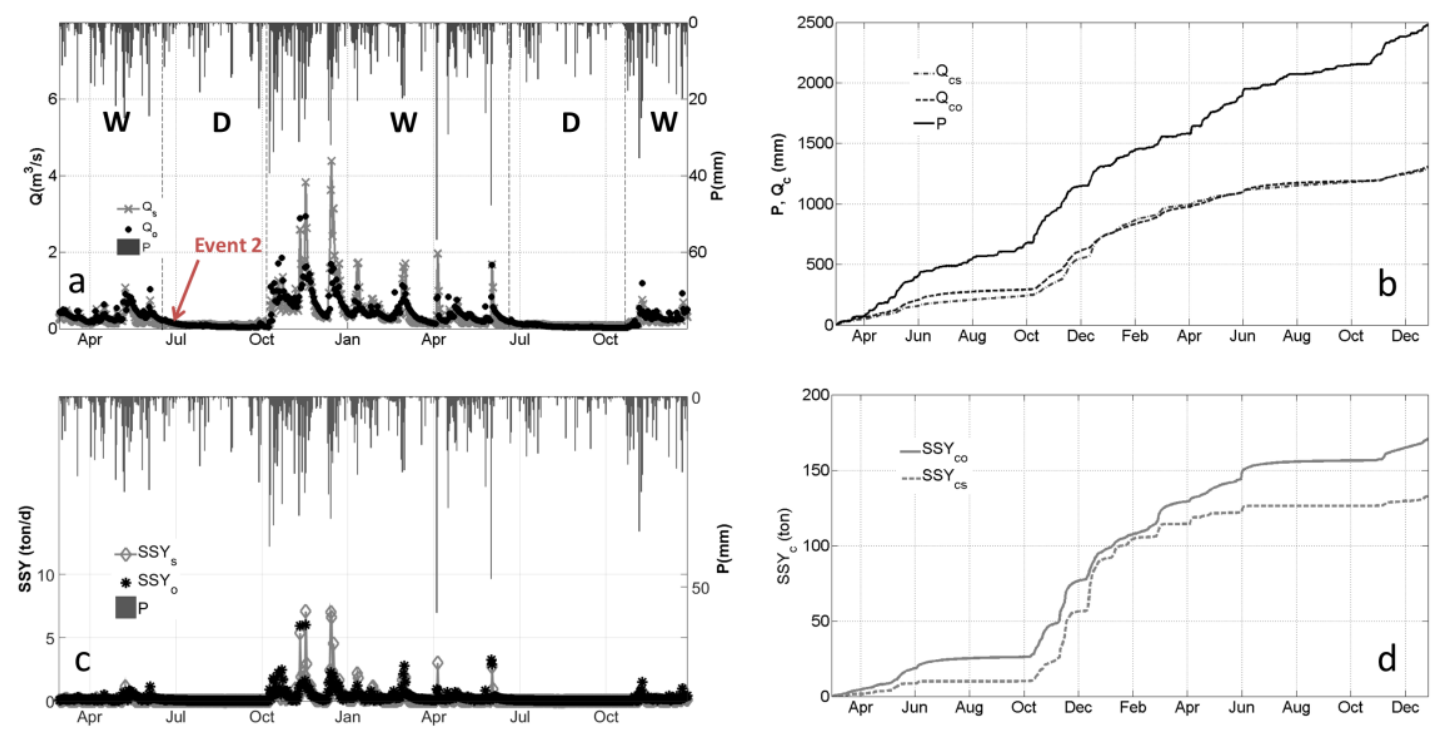

Figure 5 Model estimates of discharge and suspended sediment yield (SSY) during the validation period. (a) plot of observed and simulated daily average stream flow rate. The wet and dry periods were identified by letter ' $W$ ' and ' $D$ ' ; (b) plot of observed and simulated cumulative (with subscription ' $c$ ') stream flow volume per unit area; (c) plot of observed and simulated daily total SSY; (d) plot of observed and simulated cumulative SSY.

The performance of SSY simulation registered similar biases as that shown in streamflow simulation. The observed and simulated total annual suspended sediment losses were 170.66 and 132.48 tons, respectively (Figure 5d). The total SSY of validation period simulation had a $22.37 \%$ relative bias. The erosion model did not miss any erosion events during the validation 
period. Similar to the flow simulation results, $S S Y$ estimates were somewhat larger than observed during high flows and smaller during low flows. The RMSE was 0.41 ton/day and the value of IOA was 0.86 . NS coefficient was 0.32 . Relatively poor $N S$ coefficient is because of the metric's sensitivity to overestimation of peak flows.

Table 3 Performance of stream flow and total suspended sediment yield simulation in calibration and validation periods

\begin{tabular}{|c|c|c|c|c|}
\hline & \multicolumn{2}{|c|}{ Calibration } & \multicolumn{2}{c|}{ Validation } \\
\hline & $Q$ & $S S Y$ & $Q$ & $S S Y$ \\
\hline $\boldsymbol{N S}$ & 0.48 & 0.65 & 0.5 & 0.32 \\
\hline $\boldsymbol{I O A}$ & 0.92 & 0.93 & 0.9 & 0.86 \\
\hline $\boldsymbol{R B}$ & $15 \%$ & $9.87 \%$ & $-1.2 \%$ & $-22.37 \%$ \\
\hline $\boldsymbol{R M S E}$ & 3.03 & 0.83 & 1.47 & 0.41 \\
\hline
\end{tabular}

The model performances of flow and SSY simulation during calibration and validation periods are summarized in Table 3. The NS and IOA values of modeled flow in calibration and validation periods were similar. The RMSE of simulated flow in validation period was smaller than in calibration period. The differences between observed and simulated flow rate were smaller during the low flows than high flows. This was partly because of the longer duration of low flow during the validation period. The model performance of suspended sediment simulation in validation period was not as good as in calibration period, even though the performances of flow simulation in both periods were similar. This was due to the bias in the flow simulation and power-law relationship between flow rate and water transport capacity, which exacerbated the SSY estimates.

Table 4 Performance of stream flow and suspended sediment simulations in wet and dry periods

\begin{tabular}{|c|c|c|c|c|}
\hline & $\boldsymbol{Q}_{W}$ & $\boldsymbol{Q}_{\boldsymbol{d}}$ & $\boldsymbol{S S Y _ { w }}$ & $\boldsymbol{S S Y _ { d }}$ \\
\hline $\boldsymbol{N S}$ & 0.33 & -0.75 & 0.25 & -1.52 \\
\hline $\boldsymbol{I O A}$ & 0.88 & 0.59 & 0.85 & 0.44 \\
\hline
\end{tabular}




\begin{tabular}{|c|c|c|c|c|}
\hline $\boldsymbol{R B}$ & $4.55 \%$ & $57.58 \%$ & $-20.65 \%$ & $-95.76 \%$ \\
\hline Bias & -56.32 & 39.15 & -34.44 & -3.80 \\
\hline
\end{tabular}

In order to investigate the performance of the integrated model during markedly different flow regimes, a 20-day moving average discharge threshold of $0.2 \mathrm{~m}^{3} / \mathrm{s}$ was used to divide the simulation series into wet and dry periods (see Figure 5a). The total duration of the dry period was 173 days, almost $27 \%$ of the two years. The total precipitation during the dry period was $326.6 \mathrm{~mm}$, which is almost $11 \%$ of the total precipitation. Table 4 summaries the performances of the integrated model for both flow and SSY simulations during wet and dry periods. Both simulations showed better agreement with observed data during wet periods than in dry periods. In general, discharge volume was overestimated for dry periods and underestimated in wet periods, while the $S S Y$ was underestimated in both wet and dry periods. It is to be noted however that for large peaks, both flow rate and SSY was overestimated by the model. The negative $N S$ coefficient and relative bias indicate that the calibrated parameter set did not provide accurate enough estimates of flow and SSY during dry periods. This is in line with the findings of Jatten (1999) that showed erosion-deposition models cannot guarantee good performance, especially during dry periods, if the events used for calibration are not representative of the prevailing flow regime. It is to be noted that even though the suspended sediment simulation was not good enough during dry period, the bias of suspended sediment is only $9.94 \%$ of the total bias.

\section{Results and Analyses}

\subsection{Temporal variations in modeled estimates}

$S S Y$ from the watershed varied markedly from day to day and also non-monotonically with daily precipitation magnitude and intensity (Figure 6a). The $R^{2}$ between daily SSY and daily rainfall was only 0.14 . The $R^{2}$ between daily $S S Y$ and the product of daily total rainfall kinetic energy and maximum 30-minute rainfall intensity $\left(E I_{30}\right)$ was relatively better but still modest, and was equal to 0.53 . It is to be noted here that the lagged correlation magnitude between daily SSY and daily rainfall was maximum for a zero day lag. The large variations in daily SSY indicate that the 
daily precipitation magnitude and intensity only have a marginal potential for estimating daily $S S Y$. The variation could be because of the non-linear integrated response of the watershed, which may result in different runoff generation and hence $S S Y$ for the same daily precipitation amount and $E I_{30}$. Since runoff generation is directly influenced by the soil moisture in the surface soil layer (which in turn is influenced by groundwater depth and precipitation), we explore if the variations in daily $S S Y$ with $E I_{30}$ could be directly related to the prevailing soil moisture. To this end, data in the $S S Y$ vs $E I_{30}$ plot are color coded based on daily average soil moisture (Figure 6a). Based on the first glance, for an identical $E I_{30}, S S Y$ value appears to be larger for larger watershed-average soil moisture.
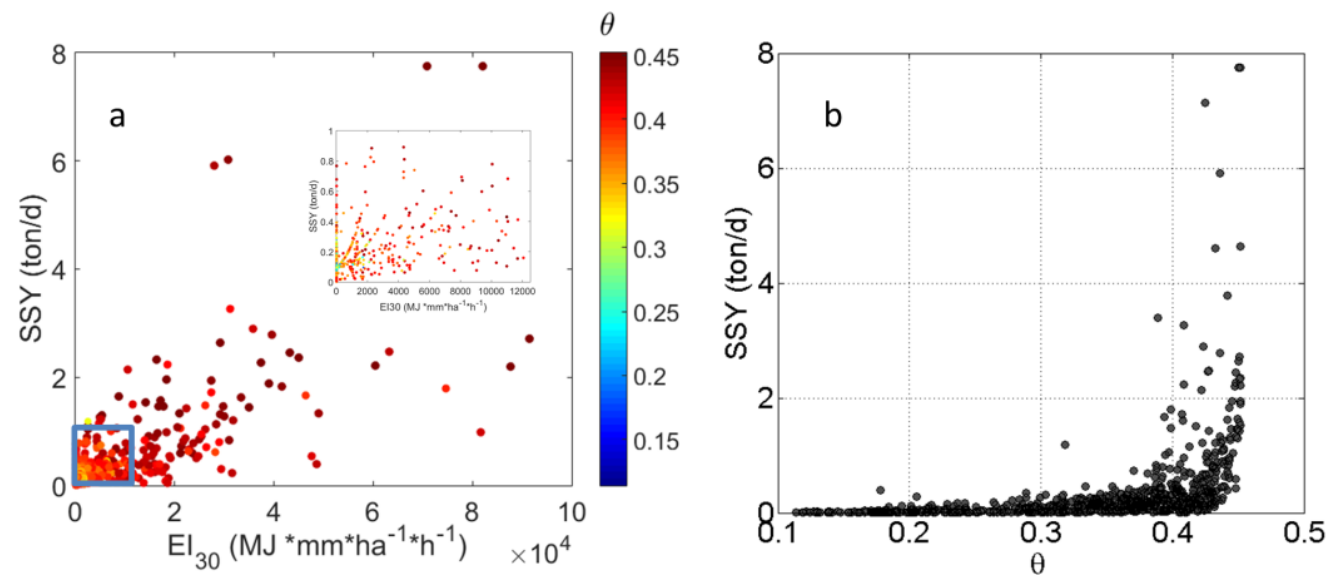

Figure 6 (a) scatter plot of daily $S S Y$ and $E I_{30}$, color mapping with daily watershed-average soil moisture; the inset figure is a zoom-in window of daily SSY between 0-1 ton/d and $E_{30}$ between $0-1.2 \times 10^{4} \mathrm{MJ}^{*} \mathrm{~mm}^{*} \mathrm{ha}^{-1} * \mathrm{~h}^{-1}$; (b) scatter plot of daily $S S Y$ from 2002 to 2003 and daily watershed average soil moisture. 

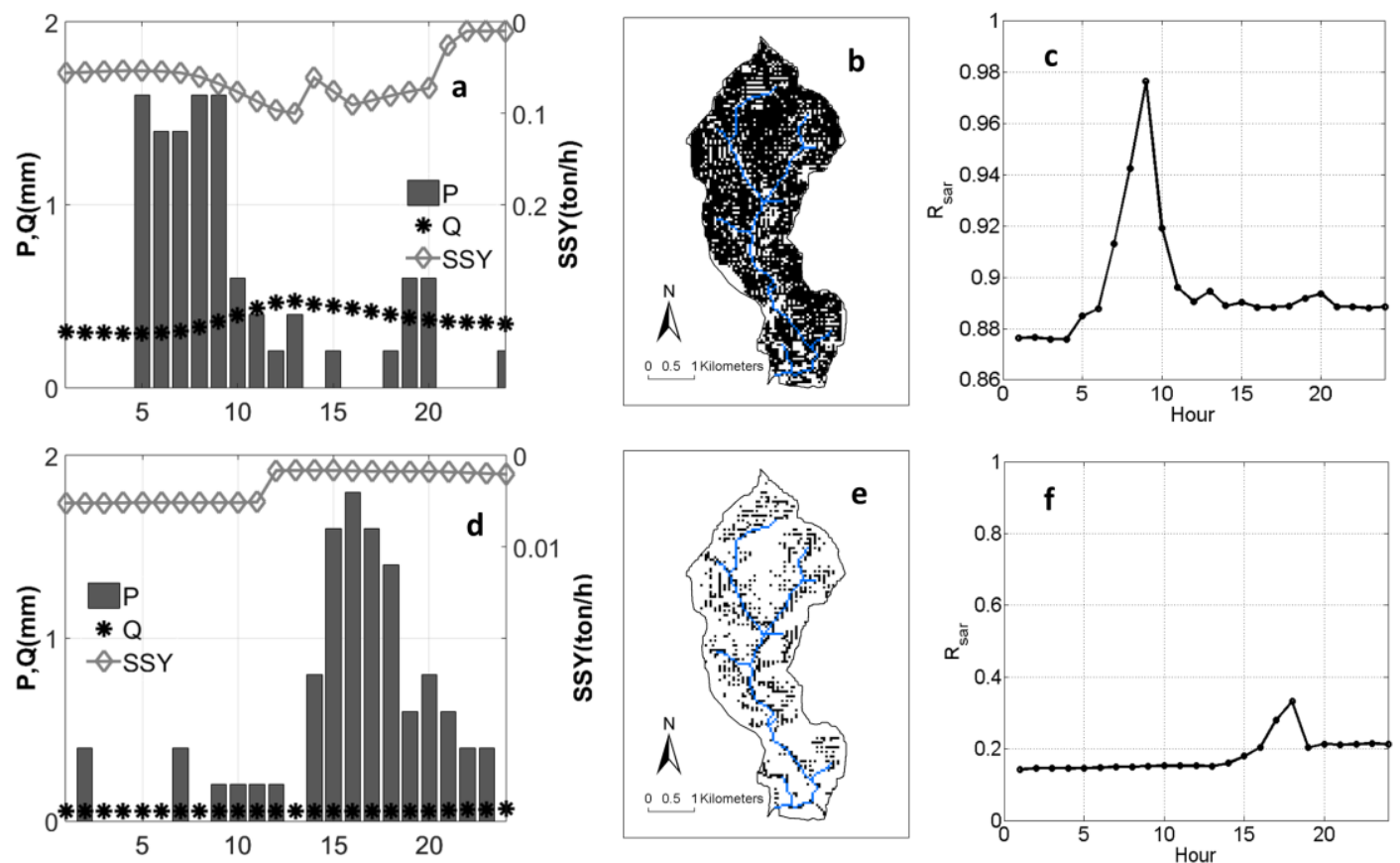

Figure 7 The hourly rainfall, discharge and SSY of two selected events (a,d); the spatial distribution of soil loss area for two selected events (b,e), area with soil losses were black; the changes of saturated ratio of the first layer soil moisture of the whole watershed $(e, f)$; the plots for first event were on the top.

To explore this further, two daily events of similar magnitude but with very different moisture conditions were considered (Figure 7). The first event occurred on 2002/1/27 (identified in Figure 4) and delivered a total precipitation of $11 \mathrm{~mm}$, a total measured streamflow of $1.3 \times 10^{5}$ $\mathrm{m}^{3}$ (modelled: $1.8 \times 10^{5} \mathrm{~m}^{3}$ ) and an event total suspended sediment yield (SSY) of 2.1 ton (modelled: 3.4 ton). The second event occurred on 2002/7/2 (identified in Figure 5) and delivered almost identical rainfall $(11.6 \mathrm{~mm}$ in total) as the first event, but the total streamflow response and SSY at the outlet were much different. Streamflow response for the second event was measured at $1.1 \times 10^{4} \mathrm{~m}^{3}$ (modelled: $1.8 \times 10^{4} \mathrm{~m}^{3}$ ), while the event mean SSY was 0.066 ton (modelled: 0.054 ton). Notably, even though the rainfall volumes and intensities were similar for these two selected events, the first event lead to much larger runoff and SSY at the outlet (Figure 7a). The difference was mostly because of strong contrast in the antecedent moisture condition between the two cases (Figure 7c and Figure 7f). Around 88\% of the watershed area was saturated at the start of event 1, with this fraction increasing to around $98 \%$ during the event. As 
a result almost the entire watershed participated in runoff generation leading to larger soil loss and mean SSY. This is not surprising as the watershed is fairly small. In contrast, only around $18 \%$ of the watershed area was saturated before event 2 and the fraction increased to around $36 \%$ during the event. Figure $8 \mathrm{~b}$ and Figure $8 \mathrm{~d}$ further reinforces the narrative that surface soil moisture influences $S S Y$ as it shows that event responses (both streamflow and SSY) were negligible for events from DOY 200 to 290 in 2002, as the soil moisture was generally below saturation during this period Figure 8c. By day 290, the water table was near the soil surface, which resulted in any additional precipitation to cause saturation excess runoff. To evaluate the variation of SSY with soil moisture across all events, a scatter plot between SSY and spatially averaged moisture conditions in the top soil layer (of thickness $=10 \mathrm{~cm}$ ) was drawn (Figure $6 \mathrm{~b}$ ). The figure suggests that runoff generation (from saturation excess or infiltration excess) and hence erosion per unit event magnitude is indeed larger when the top soil layer in the watershed is near saturation. These results suggest that accurate prediction of spatial distribution of soil moisture is critical for generating temporally fine estimates of SSY. Notably, increase in soil saturation also increases soil cohesion which in turn may reduce erosion (see Equation 7), but its impact is negated by large runoff generation for higher soil saturation cases. It is to be noted that the soil saturation of the top soil layer is a function of coupled surface water-groundwaterevapotranspiration interactions, and the parameters (such as topography, subsurface soil property, land cover etc.) that influence these processes. As such, the expressed role of surface soil moisture on SSY indirectly highlights the need for modeling of coupled processes in both space and time, much along the lines of process representations implemented in GEOtop. 

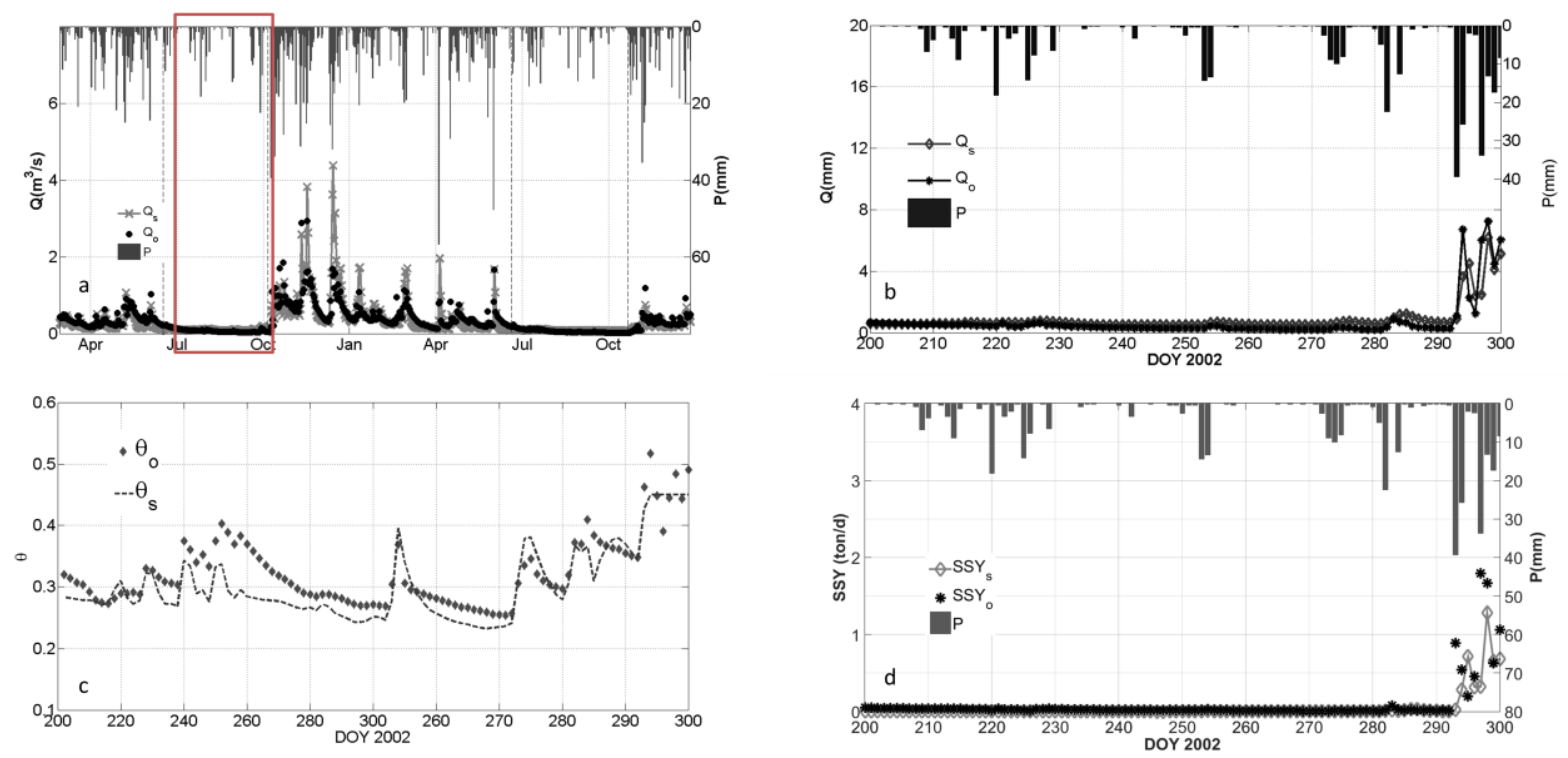

Figure 8 (a) the integrated model is able to capture occurrence of runoff events after a dry periods. The red box identifies the periods for panel b, c, and d;(b)observed and simulated flow rate; (c). observed and simulated soil moisture (top $25 \mathrm{~cm}$ ) (d)observed and simulated daily SSY

Suspended sediment yield from the watershed also showed ample variations between wet and dry periods. Even though the wet period (see Figure 5a) spanned only around $73 \%$ of the simulation time, it delivered $98.4 \%$ (99.9\%, modeled) of the total sediment yield. This is in line with previously reported results from both field $(\mathrm{Fu}, 1989)$ and modeling experiments (Baartman et al., 2012; Zhang et al., 2012) that have shown that a few extreme events may contribute to a large portion of annual total soil erosion. Notably, our research area has a temperate weather and lacks extreme precipitation events, but nonetheless the dry period $(\sim 27 \%$ of the total simulation time) delivered only $\sim 1 \%$ of the total SSY.

\subsection{Spatially distributed estimates of erosion and deposition}

Estimates of erosion and deposition simulated by the model displayed significant heterogeneity in both space and time. For example, for the two selected precipitation events with similar amounts of rainfall (Figure 7a, Figure 7d), the areal extent of soil loss and its spatial distribution locations were very different (Figure 7b, Figure 7e). The percentage area that participated in erosion loss was as high as 72\% in event 1, while reaching only around $14 \%$ for event 2 . 
Similarly the areal fraction of deposition areas were $14 \%$ and $7 \%$ respectively for the two events. A larger erosion loss area for event 1 can again be attributed to higher antecedent surface soil moisture in the watershed, which leads to a larger fraction of watershed area generating runoff. A larger volume of overland flow resulted in, higher shear stress and hence more soil loss from larger area. For the two years, the mean areal fraction of erosion and deposition was $27 \%$ and $8 \%$ respectively. Both erosion and deposition areal fraction were larger in wet periods than in dry periods. The variations of erosion and deposition areal portion were larger in wet periods (Table 5). Notably, the erosion and deposition areal fractions in the watershed were as large as $79 \%$ and $36 \%$ of the watershed area during the two year simulation periods. These statistics highlight that the source and sink areas in a watershed are very dynamic and change from event to seasonal scales. Also, given the role of soil saturation area on runoff/erosion generation, dynamic mapping of source/sink areas can benefit from spatially-explicit simulations of coupled hydrologic processes.

Table 5 The mean and variation of area portion of erosion and deposition

\begin{tabular}{|l|l|l|l|l|}
\hline & $\begin{array}{l}\text { Mean erosional area } \\
\text { fraction }\end{array}$ & $\begin{array}{l}\text { Mean depositional } \\
\text { area fraction }\end{array}$ & $\begin{array}{l}\text { Erosional area } \\
\text { fraction (standard } \\
\text { deviation) }\end{array}$ & $\begin{array}{l}\text { Depositional area } \\
\text { fraction (standard } \\
\text { deviation) }\end{array}$ \\
\hline $\mathbf{2 0 0 2 - 2 0 0 3}$ & 0.27 & 0.08 & 0.246 & 0.0859 \\
\hline Wet Periods & 0.33 & 0.11 & 0.2476 & 0.0835 \\
\hline Dry Periods & 0.11 & 0.02 & 0.1519 & 0.0585 \\
\hline
\end{tabular}




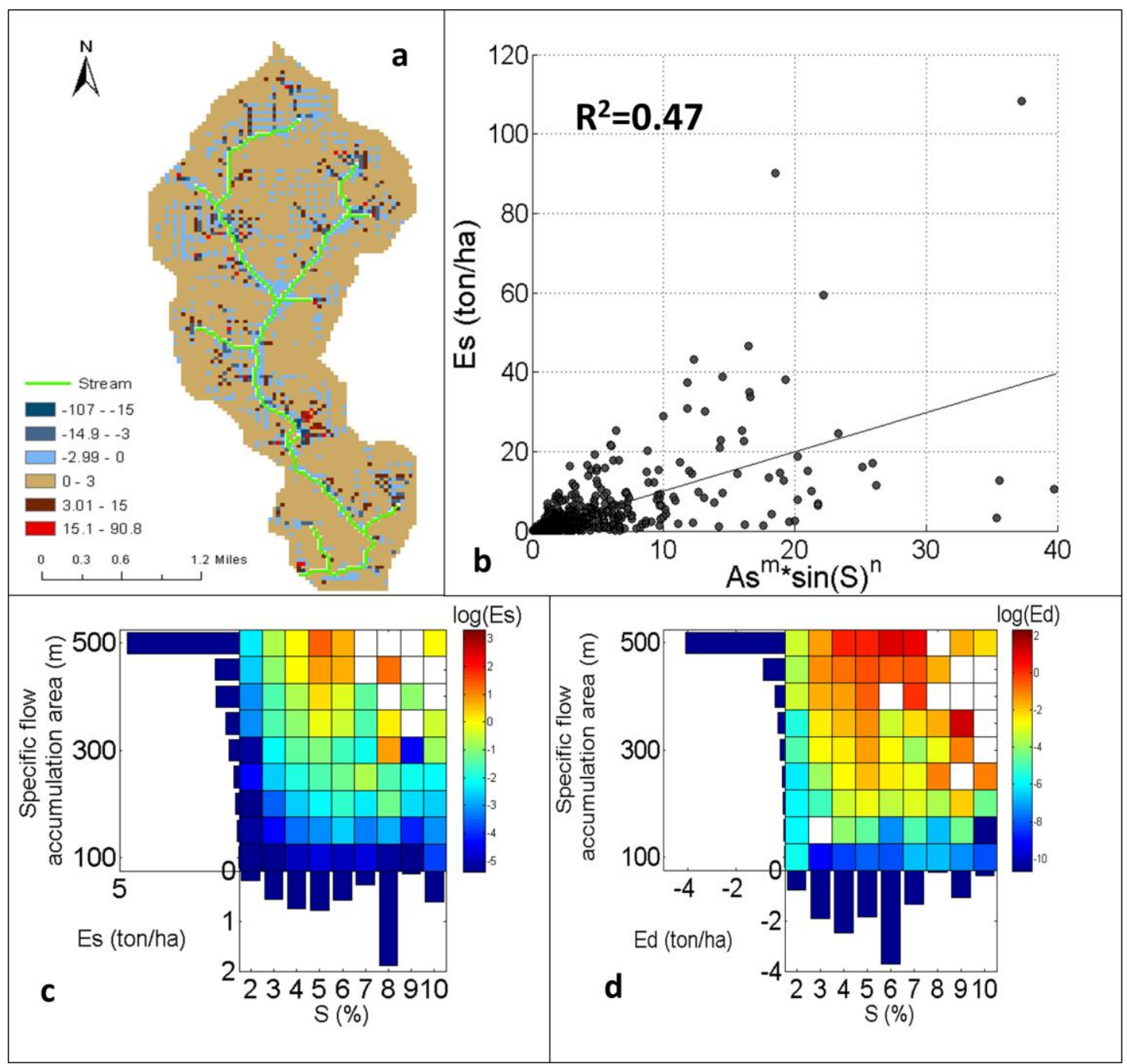

Figure 9 (a) Spatial map of soil erosion and deposition for each land pixel (unit:ton/ha/yr) for the entire two year simulation period; (b) Scatter plot between erosive loss(Es) and slope-length factor for each land pixel; (c) Color map of the logarithm of erosive loss (log(ton)) for a range of slope (on $x$-axis) and specific flow accumulation area (on y-axis). Also included on the two axes are the bar plots of total erosive losses per unit area for different Slope and specific catchment area classes; (d) Color map of the logarithm of deposition (log(ton)). Also included on the two axes are the bar plots of total deposition per unit area for different Slope and specific catchment area classes.

At the annual scale, most deposition occurred near the riparian zone of the stream (dark blue color in Figure 9a), due to its relatively flat topography. Erosive losses were mainly located in the transition area between the hillslope and the riparian zone (dark red color in Figure 9a), which had both large flow accumulation area and relatively steep slope. The locations of erosion and deposition in terms of slope and specific catchment area are shown in Figure 9c and Figure 
9d. Specific catchment area is the ratio of total contributing area of each land pixel and the pixel's width perpendicular to the flow direction. The bar plot of average erosion/deposition per unit area for different specific catchment areas shows that in general, erosion and deposition rates per unit area were larger with increasing specific catchment area. Areas with larger contributing areas generally had larger overland flow and hence larger transport capacity thus allowing more entrainment of soil particles (Figure 9c). Additionally, as more suspended sediment was transported to areas with large contribution area, the possibility that the suspended sediment concentration ( $S S C$ ) exceeded the transport capacity, especially at flatter locations, also increased. This explains the increase in deposition with larger contributing areas (Figure 9d). Notably, total simulated soil erosive losses per unit area (Es) did not show a monotonic trend with slope (Figure 9c). For flatter slopes, Es is expected to be small because of the lower flow velocities. For larger slopes, while the local erosion at the cell under consideration is expected to be large, the incoming sediment input may either be small or large for a given contributing area depending on the spatio-temporal extent of soil saturation area that determines runoff generation. As a result, $E s$, which is an integrated net-erosional response from the contributing area and the pixel under consideration, may show non-monotonic variation with slope. This non-monotonic variation also has a tangible impact on the relation between the length-slope $(L S)$ factor and the total simulated soil erosive losses per unit area $(E s)$. Model results suggest that while Es shows an overall increasing trend with $L S$ (Figure 9b), the relation is not one to one, and shows ample variations around the $E s-L S$ line $\left(R^{2}=0.47, \sigma^{2}=5.44\right)$. While the result is based on only two years of simulation, it does highlight that the source efficiency or the erosion rates (in homogeneous watersheds/hillslopes with uniform soil property) is not just a simple function of contribution area and slope, and can be strongly influenced by the dynamic spatio-temporal distribution of soil moisture conditions.

\section{Summary and Conclusions}

In this study, we developed an open-source sediment erosion/deposition module for a 3-D surface-subsurface hydrologic model, GEOtop, and evaluated its applicability in explaining the spatio-temporal distribution of erosion, deposition, and sediment yield dynamics for Dripsey 
catchment in Ireland. After performing a global multivariate sensitivity analyses to identify sensitive parameters for hydrologic modeling (such as leaf area index, rill width ratio, depth of the first soil layer, Chezy's roughness coefficient, and vertical hydraulic conductivity of the first soil layer) and sediment dynamics (such as Chezy's roughness coefficient, soil median particle size, and rill width ratio), the model performance was evaluated at daily and seasonal time scales. In general, the model reasonably simulated both the timing and magnitude of stream flow and suspended sediment yield (SSY) from the watershed. Both streamflow and suspended sediment yield simulations showed better agreement with observed data during wet periods than in dry periods. The discharge volume was overestimated for dry periods and underestimated in wet periods, while the $S S Y$ was underestimated in both wet and dry periods. Notably, the biases in suspended sediment yield simulation were similar to that shown in streamflow simulation, thus highlighting that accuracy of flow simulations critically influences the estimation accuracy of $S S Y$. While our research area has a temperate maritime climate and lacks extreme precipitation events, but still dry period ( $27 \%$ of the total simulation time) delivered only $\sim 1 \%$ of the $S S Y$. This underscores the importance of obtaining robust calibration parameter sets that at least perform well during wet periods as is well documented in in nutrient export research (Jordan et al., 2005; Nasr et al., 2007; Ye et al., 2012).

SSY from the watershed showed a non-monotonic variation with daily precipitation magnitude. Further examination revealed that $S S Y$ per unit event magnitude varied proportionally with the prevailing soil moisture. The result indicates that accurate prediction of spatial distribution of soil moisture is critical for generating temporally fine estimates of SSY. Larger SSY per unit event magnitude for higher soil saturation also indicates that large runoff generation for wetter soil moisture conditions neglected the impact of increase in soil cohesion with moisture content. The simulation results also showed that the source (erosion) and sink (deposition) areas in a watershed were heterogeneous and dynamic, and could change from one event to the next. Again, the extent of source/sink areas were found to be influenced by prevailing moisture conditions, which in turn determined the quantity of runoff generation. Model results also suggest that long-term erosion rate from a location was not just a function of its contributing area and slope. In fact, the relation between erosion and slope-length showed ample variations, thus highlighting that the source efficiency or the erosion rates (in homogeneous watersheds/hillslopes with same rainfall forcing and uniform soil property) can be 
severely influenced by the dynamic spatio-temporal distribution of soil moisture conditions. Aforementioned results clearly underscore the role of soil saturation area on erosion/ deposition distribution and sediment yield generation, and make a compelling case for spatially-explicit simulations of coupled hydrologic processes. It is to be noted though that the simulation estimates does not account for uncertainty in parameters. Further confidence in the modeled estimates could be built by obtaining field estimates of states (e.g. ground water, residence time etc.) and related parameters (e.g. rill width, soil cohesion etc.). The open-source integrated modeling framework presented here offers the potential for its use both as a prediction tool and as a virtual laboratory for understanding the role of hydrologic state impacts and parameter sensitivity on sediment dynamics.

\section{Acknowledgements}

This study was supported by the Irish Environmental Protection Agency (EPA) under the Science Technology Research \& Innovation for the Environment (STRIVE) Programme 20072013 of Ireland (Soil H: Interactions of soil hydrology, land use and climate change and their impact on soil quality; 2007-S-SL-1-S1). Mukesh Kumar acknowledges the support of National Science Foundation CZO grant (EAR-1331846). We acknowledge the developers of GEOtop model, for keeping the software open-source and free. 


\section{References}

Albertson JD, Kiely G. 2001. On the structure of soil moisture time series in the context of land surface models. Journal of Hydrology, 243: 101-119. DOI: 10.1016/s0022-1694(00)00405-4.

Baartman JEM, Jetten VG, Ritsema CJ, de Vente J. 2012. Exploring effects of rainfall intensity and duration on soil erosion at the catchment scale using openLISEM: Prado catchment, SE Spain. Hydrological Processes, 26: 1034-1049. DOI: 10.1002/hyp.8196.

Bertoldi G. 2004. The water and energy balance at basin scale: a distributed modeling approach. In: Environmental Engineering, University of Trento, pp: 202.

Bertoldi G, Della Chiesa S, Notarnicola C, Pasolli L, Niedrist G, Tappeiner U. 2014. Estimation of soil moisture patterns in mountain grasslands by means of SAR RADARSAT2 images and hydrological modeling. Journal of Hydrology, 516: 245-257. DOI: http://dx.doi.org/10.1016/j.jhydrol.2014.02.018.

Bullock MS, Kemper W, Nelson S. 1988. Soil cohesion as affected by freezing, water content, time and tillage. Soil Science Society of America Journal, 52: 770-776.

Cabral MC, Garrote L, Bras RL, Entekhabi D. 1992. A kinematic model of infiltration and runoff generation in layered and sloped soils. Adv. Water Resour., 15: 311-324. DOI: http://dx.doi.org/10.1016/0309-1708(92)90017-V.

Chen X, Kumar M, McGlynn BL. 2014. Variations in Streamflow Response to Large Hurricane-Season Storms in a Southeastern U.S. Watershed. Journal of Hydrometeorology, 16: 55-69. DOI: 10.1175/JHM-D-14-0044.1.

de Vente J, Poesen J, Verstraeten G, Van Rompaey A, Govers G. 2008. Spatially distributed modelling of soil erosion and sediment yield at regional scales in Spain. Global and Planetary Change, 60: 393415. DOI: 10.1016/j.gloplacha.2007.05.002.

Della Chiesa S, Bertoldi G, Niedrist G, Obojes N, Endrizzi S, Albertson JD, Wohlfahrt G, Hörtnagl L, Tappeiner U. 2014. Modelling changes in grassland hydrological cycling along an elevational gradient in the Alps. Ecohydrology, 7: 1453-1473. DOI: 10.1002/eco.1471.

DeRoo APJ, Wesseling CG, Ritsema CJ. 1996. LISEM: A single-event physically based hydrological and soil erosion model for drainage basins .1. Theory, input and output. Hydrological Processes, 10: 1107-1117.

Endrizzi S, Gruber S, Dall'Amico M, Rigon R. 2014. GEOtop 2.0: simulating the combined energy and water balance at and below the land surface accounting for soil freezing, snow cover and terrain effects. Geosci. Model Dev., 7: 2831-2857. DOI: 10.5194/gmd-7-2831-2014.

Franks SW, Beven KJ, Quinn PF, Wright IR. 1997. On the sensitivity of soil-vegetation-atmosphere transfer (SVAT) schemes: equifinality and the problem of robust calibration. Agricultural and Forest Meteorology, 86: 63-75. DOI: http://dx.doi.org/10.1016/S0168-1923(96)02421-5.

Fu B. 1989. Soil erosion and its control in the loess plateau of China. Soil Use Manage., 5: 76-82. DOI: 10.1111/j.1475-2743.1989.tb00765.x.

Ghimire CP, Bonell M, Bruijnzeel LA, Coles NA, Lubczynski MW. 2013. Reforesting severely degraded grassland in the Lesser Himalaya of Nepal: Effects on soil hydraulic conductivity and overland flow production. Journal of Geophysical Research: Earth Surface, 118: 2528-2545. DOI: 10.1002/2013JF002888.

Golubev GN. 1982. Soil erosion and agriculture in the world: an assessment and hydrological implications. Hydrological Sciences Journal-Journal Des Sciences Hydrologiques, 27: 243-243.

Govers G. 1990. Empirical Relationships for the Transport Capacity of Overland Flow. In: IAHS Publication, IAHS Press, Institute of Hydrology, pp: $p$ 45-63. 
Heppner CS, Loague K, VanderKwaak JE. 2007. Long-term InHM simulations of hydrologic response and sediment transport for the R-5 catchment. Earth Surface Processes and Landforms, 32: 12731292. DOI: 10.1002/esp.1474.

Heppner CS, Ran Q, VanderKwaak JE, Loague K. 2006. Adding sediment transport to the integrated hydrology model (InHM): Development and testing. Adv. Water Resour., 29: 930-943. DOI: http://dx.doi.org/10.1016/j.advwatres.2005.08.003.

Hessel R, van den Bosch R, Vigiak O. 2006. Evaluation of the LISEM soil erosion model in two catchments in the East African Highlands. Earth Surface Processes and Landforms, 31: 469-486. DOI: 10.1002/esp.1280.

Hessell R. 2005. Effects of grid cell size and time step length on simulation results of the Limburg soil erosion model (LISEM). Hydrological Processes, 19: 3037-3049. DOI: 10.1002/hyp.5815.

Hueso-González P, Ruiz-Sinoga J, Martínez-Murillo J, Lavee H. 2015. Overland flow generation mechanisms affected by topsoil treatment: Application to soil conservation. Geomorphology, 228: 796-804.

Ivanov VY, Vivoni ER, Bras RL, Entekhabi D. 2004. Catchment hydrologic response with a fully distributed triangulated irregular network model. Water Resour. Res., 40: n/a-n/a. DOI: 10.1029/2004WR003218.

Jain M, Kothyari U, Raju K. 2005. GIS Based Distributed Model for Soil Erosion and Rate of Sediment Outflow from Catchments. Journal of Hydraulic Engineering, 131: 755-769. DOI: 10.1061/(ASCE)0733-9429(2005)131:9(755).

Jetten V, de Roo A, Favis-Mortlock D. 1999. Evaluation of field-scale and catchment-scale soil erosion models. Catena, 37. DOI: 10.1016/s0341-8162(99)00037-5.

Johnson BE, Julien PY, Molnar DK, Watson CC. 2000. THE TWO-DIMENSIONAL UPLAND EROSION MODEL CASC2D-SED1. JAWRA Journal of the American Water Resources Association, 36: 31-42.

Jordan P, Menary W, Daly K, Kiely G, Morgan G, Byrne P, Moles R. 2005. Patterns and processes of phosphorus transfer from Irish grassland soils to rivers - integration of laboratory and catchment studies. Journal of Hydrology, 304: 20-34. DOI: http://dx.doi.org/10.1016/j.jhydrol.2004.07.021.

Jost G, Schume H, Hager H, Markart G, Kohl B. 2012. A hillslope scale comparison of tree species influence on soil moisture dynamics and runoff processes during intense rainfall. Journal of Hydrology, 420: 112-124.

Julien P, Simons D. 1985. Sediment transport capacity of overland flow. Transactions of the ASAE, 28: 755-762.

Kim J, Ivanov VY, Katopodes ND. 2013. Modeling erosion and sedimentation coupled with hydrological and overland flow processes at the watershed scale. Water Resour. Res., 49: 5134-5154. DOI: 10.1002/wrcr.20373.

Knisel WG. 1980. CREAMS: A field-scale model for chemicals, runoff and erosion from agricultural management systems. USDA Conservation Research Report.

Kumar M, Duffy CJ, Salvage KM. 2009. A Second-Order Accurate, Finite Volume-Based, Integrated Hydrologic Modeling (FIHM) Framework for Simulation of Surface and Subsurface Flow. Vadose Zone Journal, 8: 873-890. DOI: 10.2136/vzj2009.0014.

Laflen JM, Lane LJ, Foster GR. 1991. WEPP: A new generation of erosion prediction technology. J. Soil Water Conserv., 46: 34-38.

Legates DR, Mahmood R, Levia DF, DeLiberty TL, Quiring SM, Houser C, Nelson FE. 2011. Soil moisture: A central and unifying theme in physical geography. Progress in Physical Geography, 35: 65-86.

Lewis C. 2003. Phosphorus, Nitrogen and Suspended Sediment Loss from Soil to Water from Agricultural Grassland. In: Department of Civil and Environmental Engineering, University College Cork. 
Lewis C. 2011. Measurement and modelling of soil hydrological properties for use in the distributed rainfall runoff model - GEOtop. In: Department of Civil and Environmental Engineering, University College Cork.

Lewis C, Albertson J, Xu X, Kiely G. 2012. Spatial variability of hydraulic conductivity and bulk density along a blanket peatland hillslope. Hydrological Processes, 26: 1527-1537. DOI: 10.1002/hyp.8252.

Mati BM, Morgan RPC, Quinton JN. 2006. Soil erosion modelling with EUROSEM at Embori and Mukogodo catchments, Kenya. Earth Surface Processes and Landforms, 31: 579-588. DOI: 10.1002/esp.1347.

Miguez-Macho G, Fan Y. 2012. The role of groundwater in the Amazon water cycle: 1. Influence on seasonal streamflow, flooding and wetlands. Journal of Geophysical Research: Atmospheres (1984-2012), 117.

Montaldo N, Toninelli V, Albertson JD, Mancini M, Troch PA. 2003. The effect of background hydrometeorological conditions on the sensitivity of evapotranspiration to model parameters: analysis with measurements from an Italian alpine catchment. Hydrol. Earth Syst. Sci., 7: 848861. DOI: 10.5194/hess-7-848-2003.

Morgan RPC, Quinton JN, Smith RE, Govers G, Poesen JWA, Auerswald K, Chisci G, Torri D, Styczen ME. 1998. The European Soil Erosion Model (EUROSEM): A dynamic approach for predicting sediment transport from fields and small catchments. Earth Surface Processes and Landforms, 23: 527-544.

Nasr A, Bruen M, Jordan P, Moles R, Kiely G, Byrne P. 2007. A comparison of SWAT, HSPF and SHETRAN/GOPC for modelling phosphorus export from three catchments in Ireland. Water Research, 41: 1065-1073. DOI: http://dx.doi.org/10.1016/j.watres.2006.11.026.

Niu G-Y, Pasetto D, Scudeler C, Paniconi C, Putti M, Troch P, DeLong S, Dontsova K, Pangle L, Breshears D. 2014. Incipient subsurface heterogeneity and its effect on overland flow generation-insight from a modeling study of the first experiment at the Biosphere 2 Landscape Evolution Observatory. Hydrology and Earth System Sciences, 18: 1873-1883.

Orchard CM, Lorentz SA, Jewitt GPW, Chaplot VAM. 2013. Spatial and temporal variations of overland flow during rainfall events and in relation to catchment conditions. Hydrological Processes, 27: 2325-2338. DOI: 10.1002/hyp.9217.

Penna D, Tromp-van Meerveld H, Gobbi A, Borga M, Dalla Fontana G. 2011. The influence of soil moisture on threshold runoff generation processes in an alpine headwater catchment. Hydrology and Earth System Sciences, 15: 689-702.

Ramsankaran R, Kothyari UC, Ghosh SK, Malcherek A, Murugesan K. 2013. Physically-based distributed soil erosion and sediment yield model (DREAM) for simulating individual storm events. Hydrological Sciences Journal, 58: 872-891. DOI: 10.1080/02626667.2013.781606.

Rigon R, Bertoldi G, Over TM. 2006. GEOtop: A distributed hydrological model with coupled water and energy budgets. Journal of Hydrometeorology, 7: 371-388.

Rosenberg E, Clark E, Steinemann A, Lettenmaier D. 2013. On the contribution of groundwater storage to interannual streamflow anomalies in the Colorado River basin. Hydrology and Earth System Sciences, 17: 1475-1491.

Safeeq M, Mauger GS, Grant GE, Arismendi I, Hamlet AF, Lee S-Y. 2014. Comparing Large-Scale Hydrological Model Predictions with Observed Streamflow in the Pacific Northwest: Effects of Climate and Groundwater*. Journal of Hydrometeorology, 15: 2501-2521.

Simoni S, Zanotti F, Bertoldi G, Rigon R. 2008. Modelling the probability of occurrence of shallow landslides and channelized debris flows using GEOtop-FS. Hydrological Processes, 22: 532-545. DOI: 10.1002/hyp.6886. 
Smith RE, Goodrich DC, Quinton JN. 1995. Dynamic, distributed simulation of watershed erosion: the KINEROS2 and EUROSEM models. J. Soil Water Conserv., 50: 517-520.

Smith RE, Goodrich DC, Woolhiser DA, Unkrich CL, Singh VP. 1995. KINEROS-A kinematic runoff and erosion model. Computer models of watershed hydrology.: 697-732.

Tao J, Barros AP. 2014. Coupled prediction of flood response and debris flow initiation during warm- and cold-season events in the Southern Appalachians, USA. Hydrol. Earth Syst. Sci., 18: 367-388. DOI: 10.5194/hess-18-367-2014.

VanderKwaak JE, Loague K. 2001. Hydrologic-Response simulations for the R-5 catchment with a comprehensive physics-based model. Water Resour. Res., 37: 999-1013. DOI: 10.1029/2000WR900272.

von Freyberg J, Rao PSC, Radny D, Schirmer M. 2015. The impact of hillslope groundwater dynamics and landscape functioning in event-flow generation: a field study in the Rietholzbach catchment, Switzerland. Hydrogeology Journal: 1-14.

Wicks JM, Bathurst JC. 1996. SHESED: a physically based, distributed erosion and sediment yield component for the SHE hydrological modelling system. Journal of Hydrology, 175: 213-238. DOI: 10.1016/s0022-1694(96)80012-6.

Wu TH, McKinnell lii WP, Swanston DN. 1979. Strength of tree roots and landslides on Prince of Wales Island, Alaska. Canadian Geotechnical Journal, 16: 19-33. DOI: 10.1139/t79-003.

Yang CT. 1972. Unit stream power and sediment transport. Journal of the Hydraulics Division, 98: 18051826.

Ye S, Covino TP, Sivapalan M, Basu NB, Li H-Y, Wang S-W. 2012. Dissolved nutrient retention dynamics in river networks: A modeling investigation of transient flows and scale effects. Water Resour. Res., 48: n/a-n/a. DOI: 10.1029/2011WR010508.

Zhang $\mathrm{Y}$, Hernandez M, Anson E, Nearing MA, Wei H, Stone JJ, Heilman P. 2012. Modeling climate change effects on runoff and soil erosion in southeastern Arizona rangelands and implications for mitigation with conservation practices. J. Soil Water Conserv., 67: 390-405. DOI: 10.2489/jswc.67.5.390.

Zimmermann A, Schinn DS, Francke T, Elsenbeer H, Zimmermann B. 2013. Uncovering patterns of nearsurface saturated hydraulic conductivity in an overland flow-controlled landscape. Geoderma, 195-196: 1-11. DOI: http://dx.doi.org/10.1016/j.geoderma.2012.11.002. 